\title{
Support for Literacy Education in Academic Libraries
}

\section{Ruth J. Person and Kenneth O. Phifer}

Functional illiteracy among adults is a growing national problem, yet a scarcity of research suggests that academic libraries do not play a role in the support of literacy education efforts. To better understand the current status of academic library services to support literacy education, a survey was conducted using twenty matched pairs of community college and four-year college libraries in eight Eastern states. The study revealed that all colleges in the sample have literacy-related programs, and that nearly all of these programs received library support. In some cases this support was extensive.

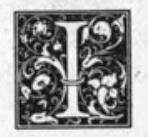

n the United States, a sophisticated nation of advanced technology, it is estimated that more than twenty-five million adults can neither read, write, nor perform basic mathematical computations. ${ }^{1}$ Because the definition of literacy now has expanded to include a more functional emphasis, i.e., possession of the essential knowledge and skills which enable a person to function effectively in his or her environment, this estimate also can be expanded to include thirty to forty million Americans who cannot function well enough to hold entry-level jobs that require such skills. ${ }^{2}$ To this pool of functionally illiterate Americans, one should add nearly half a million immigrants and refugees with multiple literacy problems. In its broadest sense, then, adult illiteracy and its concomitant problems could be termed a "U.S. disease.",3

Some of these literacy problems were addressed in the 1960s and 1970s through a variety of well-publicized and visible programs in higher education, particularly in the community college setting.
Most public community colleges developed two literacy-related goals: service to the community and provision of remedial/compensatory/developmental programs. Although four-year colleges perhaps were less likely to move in this direction, some programs for the improvement of literacy-related skills for four-year college students were in evidence.

In Functional Literacy in the College Setting, Richard Richardson discusses three kinds of college literacy-related programs. Remedial programs were designed to remedy students' deficiencies so that they could enter a program for which they were previously ineligible. Compensatory programs were designed to remedy deficiencies seen as the result of deprivation in the students' sociocultural environment. Developmental programs met students "where they were" and took them to "where they wanted to be" by dealing with both academic and human skills. ${ }^{4}$

Academic libraries and learning resource centers also played a role in literacy education in support of these college

Ruth J. Person is associate dean, School of Library and Information Science, Catholic University, Washington, D.C. 20064. Kenneth O. Phifer is librarian, Montgomery County Department of Public Libraries, Rockville, Maryland 20850. 
goals. Contributions included provision of materials for teachers, development of curriculum resource centers, actual development of teaching and learning materials, and cooperation with community programs.

In spite of growing, well-documented literacy problems, the emphasis during the 1960 s and early 1970 s on special literacy-related programs for disadvantaged students in higher education seems to have waned. Instead, the focus of literacy education efforts appears to have shifted to schools, public libraries, and community agencies. Certainly the literature reporting library support for college literacy programs is sparse, suggesting the possibility that academic libraries are not concerned with such services either because they are not deemed important or because they are not necessary, given an institutional lack of concern for literacy efforts.

As part of a general U.S. Department of Education survey of libraries and literacy, ${ }^{5}$ Smith examined over two hundred references to libraries in relation to literacy programs; there were almost no references made to the college environment. In fact, Smith's survey represents the sole major study that addresses the role of college libraries in literacy education. Even here, the college library represents only one segment of a larger library sample. On a smaller scale, Phifer and Person, ${ }^{6}$ Truett, ${ }^{7}$ and Shaughnessy ${ }^{8}$ also examined academic library services to support literacy education. Both Truett and Shaughnessy found evidence of only low levels of library support for such college programs. Also, except for the 1981 American Library Association program on "Adult Literacy: Programs and Materials," little library association programming for academic librarians is evident.

Several indicators point to an increase in the need for literacy programs in higher education. Recent studies suggest that a growing number of students will seek to enter college in the decades ahead without certain fundamental literacy skills. In discussing this "new academic revolution," the Carnegie Council predicted in 1980 that "one-half of the students in the class- rooms of the year 2000 would not have been there if the composition of 1960 had been continued." Accompanying this prediction, Richardson indicates that "special educational programs and services have increased during periods of open admissions and a need for students. ${ }^{\prime 10}$ Thus, as the pool of potential college students declines, an increasing number of enrollees will not meet traditional admission standards and will need special programs to remedy literacy deficiencies. As colleges compete for students, the literacy-related educational programs that they offer will become more and not less important.

Given these predictions, certain fundamental questions need to be reexamined. Are colleges preparing for this "new academic revolution" by providing literacyrelated programs? Has this emphasis spread to four-year colleges? How do academic libraries respond to the increased need to support such college programs? Are four-year college libraries involved in such support, or is the focus still evident largely in community college libraries?

\section{METHODOLOGY: SURVEY OF ACADEMIC LIBRARY INVOLVEMENT IN LITERACY EDUCATION}

In order to determine academic library involvement in literacy education, to explore the perceptions of academic librarians about this potential problem, and to examine the possible differences in support between junior- and senior-level institutions, a survey of two types of academic libraries in eight Eastern states was conducted. The focus of the study was on the gathering of data for twenty matched pairs of community college and four-year college libraries. These institutions represented a cross-section of both geographic settings and enrollment sizes. Because the mandate for addressing literacy problems is generally stronger in public education, only public institutions were included in the survey.

Because community colleges were expected to have a greater involvement in literacy education efforts, a questionnaire consisting of both closed and open-ended 
questions was mailed first to the directors of five community college libraries within eight Eastern states. Of these forty community colleges, thirty-one (77.5 percent) responded.

Based on this initial encouraging response, questionnaires were sent to thirty-one directors of four-year public college libraries in the same geographic area as the responding community colleges (within a fifty-mile radius). Of these, twenty (65 percent) responded. Using these four-year respondents, twenty matching pairs of academic libraries were created in order to determine possible geographic and community influences on programs and to ascertain whether a local commitment to literacy within the public education structure existed. The matching pairs of institutions represented a crosssection of both urban and rural geographic sites within each state, and a range of enrollment sizes from twelve hundred to thirteen thousand students.

The questionnaire used for both types of institutions addressed five aspects of literacy education:

- Perception of functional illiteracy as a community and college problem

- Nature of college programs for literacy education

- Relationship of the library to these college programs

- Nature of community literacy education programs

- Relationship of the library to these community literacy programs.

\section{FINDINGS}

The results of the survey suggest that higher-education institutions and their libraries are in fact making a concerted effort to solve growing literacy-related problems among students and appropriate community members. In spite of the relative scarcity of literature on the subject, activity to counteract the new wave of students with literacy deficiencies is progressing in both community and fouryear colleges and is being supported by academic libraries (see table 1 ).

There was an almost universal perception among community college respondents that functional literacy was a prob-
TABLE 1

SUMMARY DATA

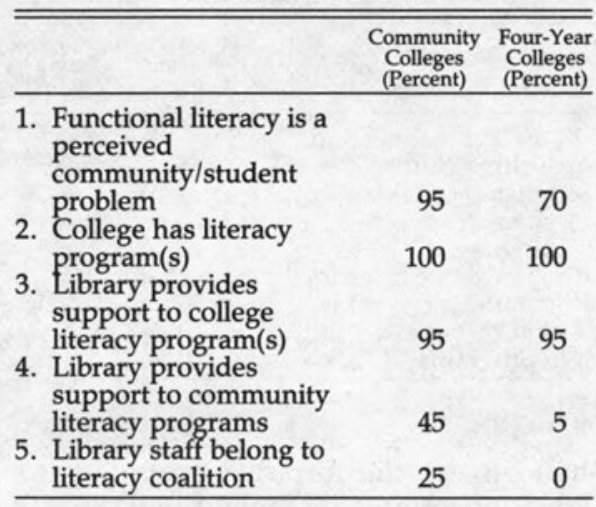

lem among their own students as well as in the larger communities of which their colleges were a part. Although somewhat less common, this view was also prevalent among the four-year college respondents. Supporting the general perception that literacy problems were a reality, every college included in the survey sponsored programs for individuals with reading and other functional literacy problems. Thus, in this sample of forty colleges, the idea that remedial/developmental/compensatory education is no longer a focus in higher education was clearly false.

The concentration of literacy-related college programs was in remedial reading and writing courses for students who had deficiencies in these areas. While both community and four-year colleges had additional programs, English courses for speakers of other languages and preparation courses for a variety of competency exams were focused more heavily in the community college. Overall, the level of involvement in the community colleges was somewhat higher for the four types of programs listed in table 2 . The average number of program types was three, while the average for four-year colleges was two.

Because all colleges in the survey provided special literacy-related programs, it might be expected that the library would support such programs. In all but one of each type of college, this was the case, although the level of support varied. The 
TABLE 2

COLLEGE LITERACY-RELATED PROGRAMS

\begin{tabular}{lcc}
\hline \hline Type of College Program & $\begin{array}{c}\text { Percent Having Program } \\
\text { Community } \\
\text { Colleges }\end{array}$ & $\begin{array}{c}\text { Four-Year } \\
\text { Colleges }\end{array}$ \\
\hline $\begin{array}{l}\text { Remedial reading and } \\
\text { writing courses } \\
\text { English courses for }\end{array}$ & 85 & 95 \\
$\begin{array}{l}\text { speakers of other } \\
\text { languages }\end{array}$ & 70 & 40 \\
$\begin{array}{l}\text { Preparation classes for } \\
\text { competency exams }\end{array}$ & 55 & 30 \\
$\begin{array}{l}\text { Other programs } \\
\text { No programs }\end{array}$ & 35 & 25 \\
\hline
\end{tabular}

majority of the libraries provided the kinds of services that might typically fall within the "traditional" mission of an academic library-making reading materials available, providing teaching materials, and offering bibliographic instruction. Services requiring a greater extension of the library's resources-program sponsorship, establishment of special collections, development of bibliographies, and the like were much less likely to be provided. The level of library cooperation at the community colleges was generally higher in terms of the ten kinds of cooperation suggested in table 3 . The average number of kinds of cooperation for community college libraries was four, whereas the average for four-year colleges was three. The percentage of community college libraries that provided each kind of service was higher than that of the four-year colleges with three exceptions. Four-year college libraries provided more bibliographic instruction, more English-as-second- language materials, and an equal number of bibliographies.

For the overall sample, there was no distinctly positive relationship between community or enrollment size and library services, although the matched pairs approach yielded eight schools with decidedly similar characteristics, as shown in figure 1. For the remaining sites, such relationships were much less apparent. For example, four minimally involved libraries were in small communities, but one was located in a city of two million. Conversely, one of the most actively involved libraries, which sponsored student tutorial programs and reading laboratories, was located in a rural environment, while another which provided a full range of services was located in a major metropolitan area.

In spite of the traditional nature of library services offered, the degree of collaboration between faculty and library staff in collection development related to literacy materials was promising. At the community college level, close to twothirds of the libraries cooperated with academic departments in this effort. At the four-year colleges, half of the libraries reported cooperative efforts. This collaboration was in marked contrast to the low level of cooperation reported by Shaughnessy in his earlier study of educational opportunity programs. ${ }^{11}$ Likewise, some noteworthy programs extended library services-for example, one community college library developed a "minicourse" for classroom instructors, librarians, tutors, administrators, and

LIBRARY COOPERATION IN COLLEGE LITERACY EFFORTS

Cooperation Provided by Library

1. Make reading materials available

Percent Providin Community Four-Year

2. Provide teaching materials

75

75

60

50

3. Provide bibliographic instruction

50

4. Provide space for classes and labs

5. Develop reading and writing labs

6. Maintain bibliographies of instructional materials and adult books in simple language

. Set up special shelves of high-interest/low-vocabulary material for adults

8. Set up shelves for material on English-as-a-second-language

9. Sponsor the program

10. Sponsor tutorial programs using student volunteers 
- Extensive college involvement in literacy education

- Awareness of literacy problem and community literacy programs among library directors

- Faculty/library staff collaboration in collection development

- Metropolitan location

- Large enrollment

- Extensive community involvement in literacy education

\section{FIGURE 1}

Characteristics of "High Involvement" Pairs

adult educators on "How to Establish Reading Levels for Library Materials," while a four-year college offered a program called "Setting the Book Straight."

While there were many similarities both in the level of college involvement in programs and in library support for such programs, the differences between community and four-year colleges were more readily apparent when examining the relationship of libraries to the community at large. While three-fourths of the community college respondents and half of the four-year college respondents indicated that they knew of other providers of literacy education in their respective communities, only half of these libraries actually worked with such agencies, and almost all of those were community colleges. Paralleling library involvement in college literacy programs, the major services provided were reading materials, teaching materials, and bibliographic instruction. One-fourth of the community college library directors indicated that they or their staff participated in a coalition of agencies concerned with literacy. No four-year directors indicated such participation.

In an effort to understand more about the possible influence of geographic area, enrollment size, and general community "climate" on a library's willingness to participate in and support literacy education efforts, the matched pairs approach was used. In most cases, in spite of initial expectations that community college libraries would have a much heavier in- volvement in providing services than their four-year counterparts, there were striking similarities between most of the pairs of schools. Sixteen pairs of libraries had similar levels of involvement, which ranged upward from moderate (one and two types of support efforts) to very high (in the case of four pairs).

Among these four "high involvement" pairs, the colleges themselves were heavily involved in special literacy programs (all four of the kinds of programs represented in table 2 were indicated). Library directors at these colleges all indicated an awareness of literacy problems both in the community and among students, as well as of community literacy education efforts. All of these respondents indicated that faculty and library staff collaborated in library collection development for literacy-related materials.

All eight of the schools in the matched pairs were located in or near metropolitan areas with a population of two hundred thousand or more and were at the upper end of the enrollment-size range for the sample. While it is difficult to generalize from such a small sample, this location and enrollment combination suggests that institutions with these characteristics have not only a heightened awareness of literacy problems but undoubtedly greater resources to undertake programs; they may also have a greater demand for a multiplicity of efforts to support diverse population needs. In all eight schools, community involvement in literacy education efforts was also high, suggesting that in these locations, a concerted effort was being made to remedy literacy problems at all levels.

\section{CONCLUSIONS AND RECOMMENDATIONS}

In one way it is discouraging to learn that more than three-fourths of the library directors in this survey viewed literacy as a problem in their environment. At the same time, it is encouraging to note a realistic level of awareness among the respondents and their involvement in solving this growing national problem. In spite of the scarcity of literature on library services to college literacy education programs, 
this survey suggests that academic libraries have an important role to play in such programs, and that this mission is being carried forward by the respondents. Further, the study indicates that, at least for this sample, comparable efforts are being undertaken in the two-year and fouryear college library settings.

The results of the study also suggest two possible directions for further study and improvement of library services in order to meet the challenges of the "new academic revolution." Literacy education services provided most often by the libraries in this survey represented a generally passive approach, such as making materials available and providing bibliographic instruction when requested. Even within this somewhat traditional framework, several kinds of services could be improved without extensive effort. In particular, bibliographies of available instructional materials and adult books in simple language are an important part of the teaching-learning process and could easily be supplied. Likewise, special shelves of materials for individuals with literacy problems could be provided.
In the face of declining revenues, there is also room for more active involvement by improving the degree of cooperation with faculty, other educational institutions, and community agencies. Such cooperation can produce more comprehensive services and prevent duplication of effort. The most comprehensive involvement in literacy education support can be accomplished through cooperative efforts in which each participating organization provides a set of services that capitalizes on its expertise. The college library administration and staff first must define their role in literacy education and perceive their involvement as appropriate. Cooperating agencies also must recognize the library as a useful resource. Then, when each agency is involved in the planning, development, and evaluation of literacy education programs, successful implementation will more likely occur. This increased level of cooperation and understanding will be our most valuable ally in confronting the "new academic revolution" and its accompanying literacy problems.

\section{REFERENCES}

1. Jonathan Kozol, "How We Can Win: A Plan to Reach and Teach Twenty-Five Million Illiterate Adults," Wilson Library Bulletin 54:640 (June 1980).

2. Ibid.

3. Carman Hunter and David Harman, Adult Illiteracy in the United States (New York: McGraw-Hill, 1979), p.1.

4. Richard Richardson, Kathryn Martens, and Elizabeth Fisk, Functional Literacy in the College Setting (Washington, D.C.: American Assn. for Higher Education, 1981), p.5.

5. Ester G. Smith, Libraries in Literacy (Washington, D.C.: U.S. Department of Education, 1981).

6. Kenneth O. Phifer and Ruth J. Person, "The Role of Community College Libraries and Learning Resource Centers in Literacy Education," Community \& Junior College Libraries 2:9-22 (Fall 1983).

7. Carol Truett, "Services to Developmental Education Students in the Community College: Does the Library Have a Role?" College \& Research Libraries 44:20-28 (Jan. 1983).

8. Thomas W. Shaughnessy, "Library Services to Educationally Disadvantaged Students," College \& Research Libraries 36:443-48 (Nov. 1975).

9. "Carnegie Panel Says Enrollment Declines Will Create a New Academic Revolution," Chronicle of Higher Education 19:11 (Jan. 28, 1980).

10. Richardson, Martens, and Fisk, Functional Literacy in the College Setting, p.3.

11. Shaughnessy, "Library Services," p.443-48. 